\title{
Diagnosis and management of primary ciliary dyskinesia
}

\author{
Claudius Werner*, Jörg Große Onnebrink and Heymut Omran
}

\begin{abstract}
Primary ciliary dyskinesia (PCD) is a rare autosomal recessive disorder with defective structure and/or function of motile cilia/flagella, causing chronic upper and lower respiratory tract infections, fertility problems, and disorders of organ laterality. Diagnosing PCD requires a combined approach utilizing characteristic phenotypes and complementary methods for detection of defects of ciliary function and ultrastructure, measurement of nasal nitric oxide and genetic testing. Currently, biallelic mutations in 31 different genes have been linked to PCD allowing a genetic diagnosis in approximately $\sim 60 \%$ of cases. Management includes surveillance of pulmonary function, imaging, and microbiology of upper and lower airways in addition to daily airway clearance and prompt antibiotic treatment of infections. Early referral to specialized centers that use a multidisciplinary approach is likely to improve outcomes. Currently, evidence-based knowledge on PCD care is missing let alone management guidelines. Research and clinical investigators, supported by European and North American patient support groups, have joined forces under the name of BESTCILIA, a European Commission funded consortium dedicated to improve PCD care and knowledge. Core programs of this network include the establishment of an international PCD registry, the generation of disease specific PCD quality of life questionnaires, and the first randomized controlled trial in PCD.
\end{abstract}

\section{Review}

The term primary ciliary dyskinesia (PCD (MIM 244400)) has been used for a clinically and genetically heterogeneous group of recessive disorders with defective ciliary motility resulting in chronic upper and lower respiratory tract disease. Organ laterality defects occur in approximately $50 \%$ of cases, usually situs inversus totalis (Kartagener's syndrome). In 1976, Afzelius reported that PCD is characterized by ultrastructural defects of cilia leading to 'immotile' cilia [1]. Subsequent research lead to the replacement of the term 'immotile cilia syndrome' by 'primary ciliary dyskinesia' in order to emphasize that not only ciliary immotility but also abnormal ciliary motility causes PCD [2]. Even this term seems to be inappropriate to cover all disease variants, as demonstrated by the recent identification of a disease entity characterized by typical, severe clinical PCD features (without situs abnormalities) caused by defective generation of multiple motile cilia [3,4]. This review provides a state-of-the art overview on diagnosis and management of PCD. It augments knowledge summarized

\footnotetext{
*Correspondence: Claudius.Werner@ukmuenster.de Department of General Pediatrics, Pediatric Pulmonology Unit, University

Children's Hospital Muenster, Albert-Schweitzer-Campus 1, Geb. A1, D-48149 Münster, Germany
}

(c) 2015 Werner et al.; licensee BioMed Central. This is an Open Access article distributed under the terms of the Creative Commons Attribution License (http://creativecommons.org/licenses/by/4.0), which permits unrestricted use, distribution, and reproduction in any medium, provided the original work is properly credited. The Creative Commons Public Domain Dedication waiver (http://creativecommons.org/publicdomain/zero/1.0/) applies to the data made available in this article, unless otherwise stated.

in recent reviews [2,5-10]. Due to the thematic overlap, partial similarities to these reviews are inevitable.

\section{Epidemiology}

The PCD prevalence is difficult to determine [11] and is in the range of 1:4,000 to $<1: 50,000$ [12]. Most likely, this rather reflects differences in access to diagnostic facilities as several complex diagnostic tests, which are not universally available, have to be combined for diagnosing PCD. On the other hand, some degree of variability can be explained by a higher prevalence in societies with a high degree of consanguinity [13].

\section{Diagnosis}

PCD is both under-diagnosed and diagnosed too late [12]. Therefore, clinicians should increase their level of suspicion for PCD in patients with typical phenotypes (Table 1). Diagnosing PCD requires a combined approach of complementary methods (Table 2; Figure 1), all of which have limitations $[2,14]$. As most institutions do not have adequate resources for a thorough diagnostic evaluation, referral to specialized centers is strongly recommended $[2,6,11]$. 
Table 1 Candidates for primary ciliary dyskinesia (PCD) testing (adapted from $[5,11]$ )

1. Individuals with situs inversus totalis or other situs abnormalities

2. Individuals with both upper and lower respiratory tract disease

a. Upper airways disease includes: chronic rhinitis/nasal discharge, chronic sinusitis, hearing impairment due to glue ear, chronic otitis media

b. Lower airways disease includes: chronic wet cough, atelectasis or bronchiectasis, notably in middle lobe, lingula or lower lobes, chronic/recurrent bronchitis/pneumonia

3. History of unexplained neonatal respiratory distress

4. Positive family history (for example, affected sibling)

5. Congenital heart defect, notably if upper/lower airways disease and heterotaxy are present

\section{Clinical phenotype}

Up to $85 \%$ of individuals with PCD have a history of unexplained neonatal respiratory distress [15]. Symptoms comprise mild transient tachypnoea, atelectasis, and can advance to respiratory failure requiring ventilatory support. Directly after birth, neonates with PCD present with persistent rhinitis or a blocked nose leading to feeding difficulties. Chronic rhinosinusitis develops in childhood and lasts through adulthood (Figure 2). Already during infancy, conductive hearing loss frequently occurs due to middle ear effusion that may progress to glue ear. Infants typically develop daily wet cough and recurrent upper and lower airways infections. Although a life-long symptom, patients often do not report cough as under-recognition due to adaptation to this ever-present symptom or cough suppression due to embarrassment are common. Consolidation, atelectasis, and bronchiectasis are constant findings in adults but may be present already in infancy (Figure 2) [15]. Typically, the middle and lingula lobes of the lung are affected predominantly followed by the lower lobes. Involvement of the upper lobes usually occurs at a later disease stage [16].

In many PCD variants, ciliary dysfunction also involves cilia of the embryonic node which are essential for establishing the left-right asymmetry of visceral organs. Dysfunction of these nodal cilia results in a randomization of left-right body asymmetry. Hence, $40 \%$ to $50 \%$ of PCD individuals present with situs inversus totalis, a condition known as Kartagener's syndrome, and a smaller subset of individuals (at least 6.3\%) display complex situs anomalies associated with congenital heart disease [17]. Of note, respiratory symptoms are very common in patients with heterotaxy and complex cardiac disease due to the heart defect [18]. Thus, these patients have a high risk that PCD, a chronic respiratory disease requiring specific management, may be overlooked.

As the structure of sperm flagella is similar to the ciliary axoneme, many PCD variants are associated with male infertility. By contrast, it is yet unclear to what extent women with PCD are affected by subfertility due to dysfunction of cilia in the fallopian tubes.

\section{Nasal nitric oxide}

Measuring nasal nitric oxide (nNO) is a very robust screening test for PCD as values are very low in most PCD patients [19-21]. nNO is analyzed by placing a nasal olive probe into one nostril with a tube connecting the olive with the analyzer. The measurement is done while the patient performs an exhalation against resistance manoeuver in order to close the soft palate and thereby separate the sinonasal compartment from the bronchial airflow. Among several commercially available NO analyzers, most data on reliability and validity exist with chemiluminiscence analysers. Using such a device, a $\mathrm{nNO}$ production rate less than $77 \mathrm{~nL} / \mathrm{min}$ has a sensitivity and specificity of 0.98 and $>0.999$, respectively, for PCD diagnosis [20]. As breathing manoeuvers are difficult particularly for young children, simpler tests such as tidal breathing sampling are currently evaluated [22,23]. nNO should not be used as single diagnostic test because low levels can also be present in cystic fibrosis (CF), sinusitis, nasal polyposis, and acute upper airways infections and because normal $\mathrm{nNO}$ levels rarely have been reported in PCD patients [21].

\section{High-speed video microscopy}

High-speed video microscopy (HVMA) of ciliary beat pattern and frequency of respiratory epithelial cells obtained by trans-nasal brushing currently is the first-line diagnostic test in many centers. Cilia can be observed at

\section{Table 2 Methods and limitations used for confirmation of PCD diagnosis}

\begin{tabular}{ll}
\hline Method & Limitation \\
\hline Nasal NO level & $\begin{array}{l}\text { May be decreased in other disorders, for example, acute sinusitis or cystic fibrosis; rarely normal } \\
\text { values may be present in PCD }\end{array}$ \\
High frequency video microscopy (HVMA) & $\begin{array}{l}\text { Variants with subtle beating abnormality may be interpreted as normal; secondary ciliary dyskinesia } \\
\text { due to infection and inflammation is very common - distinction from PCD phenotype may be difficult }\end{array}$ \\
Transmission electron microscopy (TEM) & $\begin{array}{l}\text { Approximately 30\% of PCD cases have no ultrastructural abnormality; false-positive diagnoses } \\
\text { common in some variants (notably inner dynein arm defects) }\end{array}$ \\
Immunofluorescence microscopy (IF) & No abnormality in approximately $\sim 20 \%$; technical difficulties if specimen contains a lot of mucus \\
Genetics & Expensive due to high number of PCD genes; only approximately 60\% of cases can be identified \\
\end{tabular}



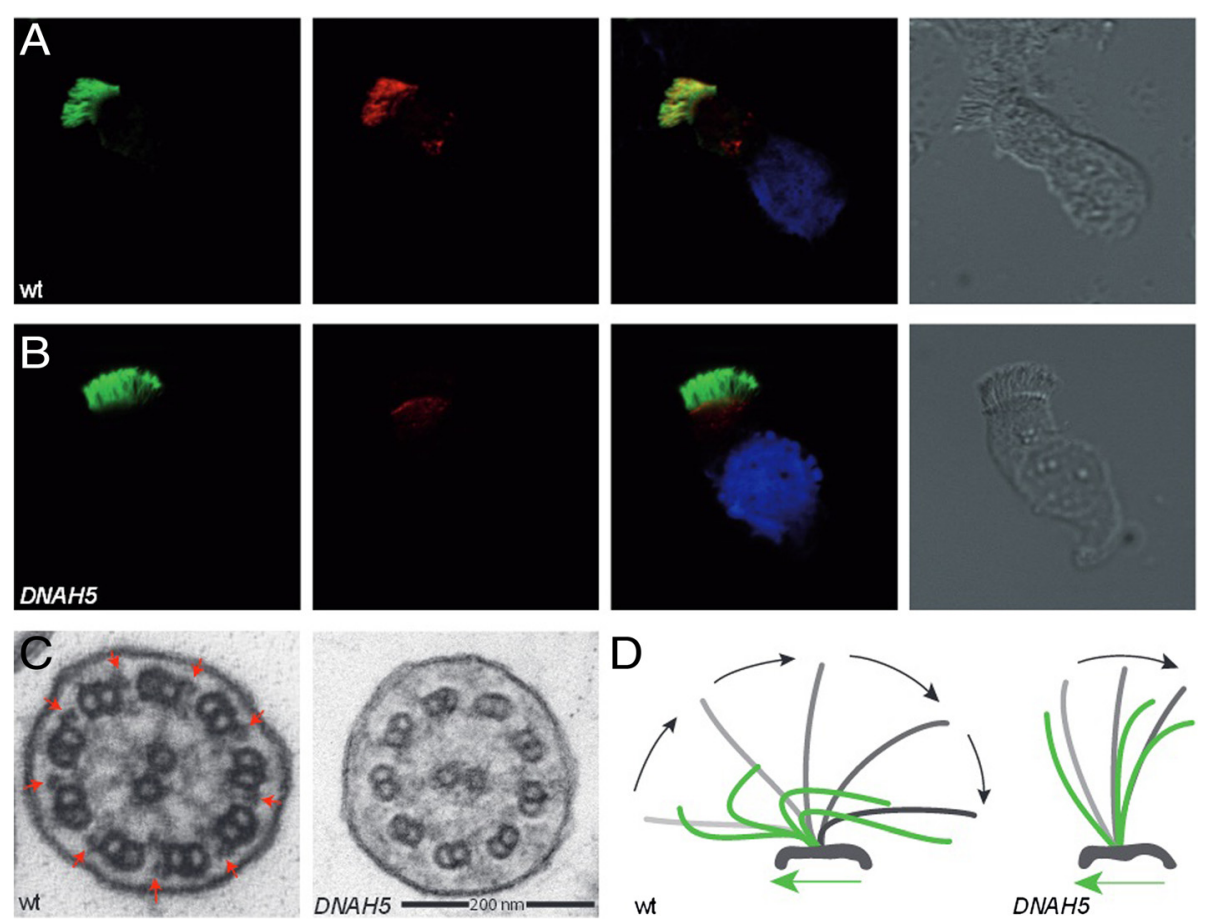

Wt

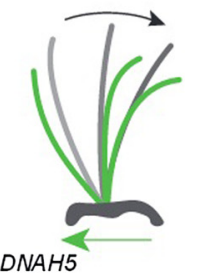

Figure 1 Methods used for PCD diagnosis. (A, B) Immunofluorescence co-staining of human respiratory epithelial cells with DNAH5-specific antibodies (red) and antibodies against acetylated a-tubulin (green). Nuclei were stained with Hoechst 33342 (blue). Overlays and bright-field images are shown on the right. Whereas in healthy human respiratory epithelial cells (wt, A) both DNAH5 and acetylated a-tubulin antibodies co-localize along the entire length of the ciliary axonemes, in an individual with an outer dynein arm defect (B), the ODA heavy chain DNAH5 is absent from the axonemes. (C) Transmission electron tomography of healthy respiratory epithelial cells (wt) showing no ultrastructural abnormality. Outer dynein arms (ODAs) are highlighted with red arrows. In an individual with DNAH5 mutations, ODAs are missing. (D) Diagram of ciliary beat patterns as deduced from high-speed videomicroscopy. A normal ciliary beat pattern (wt) is characterized by a strong beating stroke (symbolized in grey) followed by a recovery stroke (symbolized in green). In DNAH5 mutant cilia, only a minimal residual ciliary activity is present.

high-resolution in real time and with slow-motion replay [24]. HVMA is performed directly after obtaining the specimen and immediately yields a definite diagnosis in a subset of cases. Ciliary beat abnormalities include static cilia, almost static cilia with minimal movements, stiff beating due to a reduced bending capacity/amplitude, abnormal circular beating and hyperkinetic cilia. These patterns are linked with specific ultrastructural defects and genetic variants [24]. Thus, HVMA findings can guide subsequent analyses revealing the underlying molecular defect. HVMA though is a challenging method for various reasons: (1) HVMA protocols differ among centers in many aspects: sampling techniques, microscopes and cameras, temperature during analysis, software, and evaluation criteria [24]; (2) Whereas ciliary beat frequencies can be determined easily, development of objective methods to reliably distinguish PCD-specific ciliary beat pattern abnormalities from normal findings or secondary damage are at a very provisional stage [25]. Thus, HVMA evaluation remains strongly dependent on the experience of the investigator; (3) Recent molecular findings have revealed PCD variants that may easily be misinterpreted as normal [26,27] or difficult to assess due to lack of ciliated tissue caused by defects of multiple motile cilia generation [3,4]; (4) Acute or chronic infection and inflammation - very common both in PCD and non-PCD individuals - lead to secondary ciliary dyskinesia that may be difficult to distinguish from primary ciliary dyskinesia [2,28]. To overcome diagnostic difficulties related to secondary abnormalities caused by infection and inflammation, HVMA as well as transmission electron microscopy (TEM; see below) or immunofluorescence analysis (IF; see below) can be performed additionally after in vitro ciliogenesis in respiratory epithelial cell cultures. Although the ciliary beating phenotype may be altered after cell culture, primary abnormalities are still present $[29,30]$.

\section{Assessment of ciliary composition by transmission electron microscopy or immunofluorescence analysis}

Analysis of ciliary cross-sections by TEM has been used traditionally to confirm a PCD diagnosis. However, as this approach cannot be used to identify an increasing number of PCD variants (at least 30\%; [31,32]) with (near) normal ultrastructure, this approach can no longer be the 'gold 


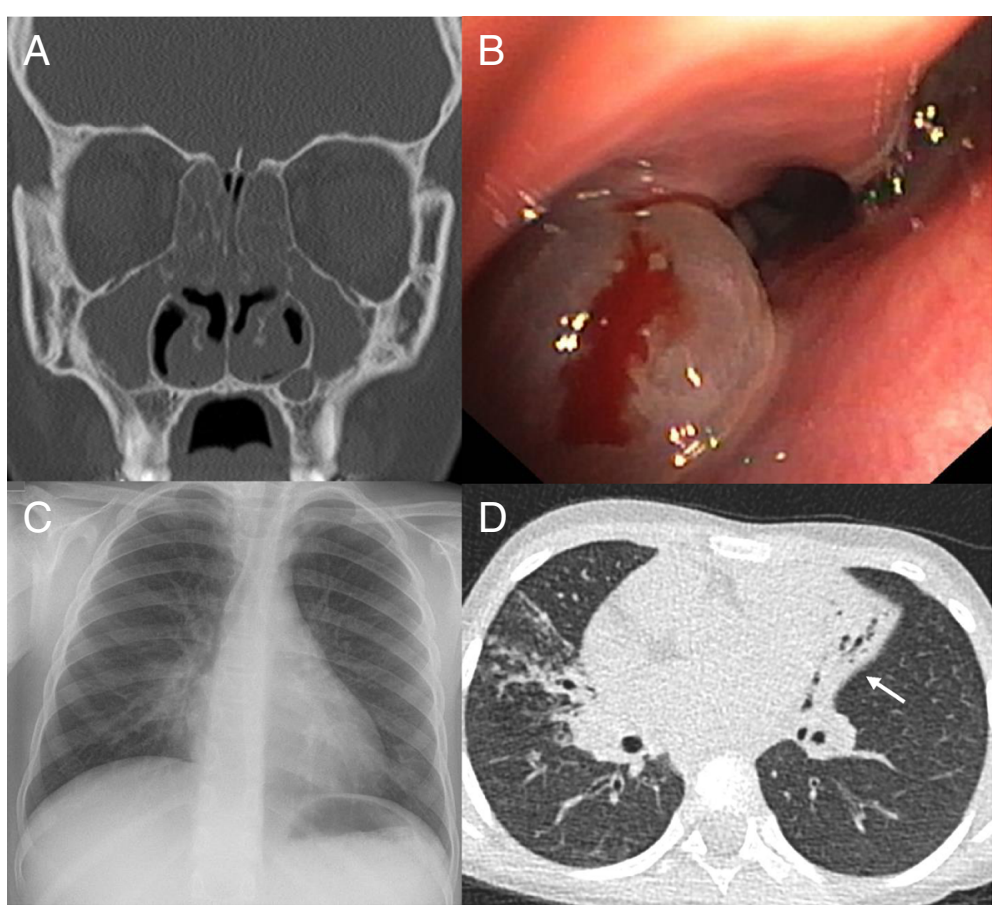

Figure 2 Clinical features of primary ciliary dyskinesia. (A) Coronal computed tomography (CT) scan of a 17-year-old PCD individual showing diffuse pansinusitis with mucosal thickening and polyposis. (B) Endoscopic view showing nasal polyp (same patient). (C) Chest X-ray of a 6-yearold PCD individual with middle lobe atelectasis. Silhouetting of the right heart border is present. (D) Chest CT of a 6-year-old individual with situs inversus totalis. The left-sided middle lobe shows extensive bronchiectasis with volume loss (white arrow). In addition, consolidations and mucous impaction are present in the right upper lobe.

standard' for diagnosis. Defects that can reliably be identified by TEM include a complete or partial absence of outer dynein arms (ODAs; Figure 1), combined ODA and inner dynein arm (IDA) defects, and microtubular disorganization defects. Isolated IDA defects should not be diagnosed by a single TEM analysis alone as falsepositive diagnoses commonly occur with isolated IDA defects [33]. Only a subset of radial spoke defects can be diagnosed by TEM analyses [34]. Defects of nexin link components [26,35], central pair components [27], ciliary biogenesis defects [3,4] and defects caused by DNAH11 mutations $[31,36]$ usually cannot be identified by routine TEM analysis.

During the last decade, high resolution IF has been introduced as an additional tool to investigate the subcellular localization of the ciliary proteins in human respiratory epithelia [37]. Meanwhile, it is possible to reliably identify all ultrastructural abnormalities detectable by TEM, such as outer dynein arm defects (Figure 1) or microtubular disorganization with IDA defect [37-39], and additionally abnormalities of nexin links components [26] and radial spoke head proteins $[40,41]$. The technology has been adopted by several laboratories and it is likely that further development will allow recognizing an increasing number of PCD variants.

\section{Genetics}

PCD is an autosomal recessive disorder. Mutations in a rapidly expanding number (currently 31 ) of genes are disease-causing (Table 3). The majority of mutations are loss-of-function variants, while missense mutations can be found in a minority of cases. Most mutations are private. Clustering of mutations in specific genetic regions is less common than in other genetic disorders. The specific gene mutations correlate to their structural and video microscopic phenotype.

Only preliminary evidence correlates genetic findings with distinct clinical phenotypes. Mutations affecting the composure of the central pair (HYDIN [27]) or radial spokes (RSPH1 [34,40], RSPH4A, RSPH9 [59]) as well as the generation of multiple motile cilia (MCIDAS [3], CCNO [4]) do not result in situs abnormalities. Patients with mutations in RSPH1 may have a milder clinical course [34]. Males with mutations in CCDC114 are not affected by infertility due to sperm immotility [47]. Subjects with reduced generation of multiple motile cilia may have a more severe respiratory disease with lung failure at younger age $[3,4]$.

Modern high-throughput genetic technologies allow identification of disease-causing biallelic mutations in approximately $\sim 60 \%$ of patients. Although not yet 
Table 3 Genes associated with PCD and corresponding ultrastructure

\begin{tabular}{|c|c|c|c|c|c|c|}
\hline \multirow[t]{2}{*}{ Gene } & \multirow[t]{2}{*}{ Reference } & \multirow{2}{*}{$\begin{array}{l}\text { Axonemal/cellular } \\
\text { structure or function }\end{array}$} & \multicolumn{2}{|l|}{ Routine TEM } & \multicolumn{2}{|l|}{ Routine IF } \\
\hline & & & Informative ${ }^{a}$ & Finding & Informative $^{a}$ & $\begin{array}{l}\text { Abnormal staining with } \\
\text { antibodies against }\end{array}$ \\
\hline $\begin{array}{l}\text { DNAH5, DNAI1, DNAI2, } \\
\text { DNAL1, NME8 (TXNDC3) }\end{array}$ & {$[42-46]$} & ODA subunit & $\checkmark$ & ODA-defect & $\checkmark$ & ODA component \\
\hline $\begin{array}{l}\text { CCDC114, ARMC4, } \\
\text { CCDC151 }\end{array}$ & [47-49] & $\begin{array}{l}\text { ODA targeting/docking } \\
\text { factor }\end{array}$ & $\checkmark$ & ODA-defect & $\checkmark$ & ODA component \\
\hline $\begin{array}{l}\text { DNAAF1 (LRRC50), } \\
\text { DNAAF2 (KTU), DNAAF3, } \\
\text { HEATR2, LRRC6, } \\
\text { ZMYND10, DYX1C1 } \\
\text { (DNAAF4), SPAG1, } \\
\text { CCDC103, C21ORF59 }\end{array}$ & {$[38,50-58]$} & $\begin{array}{l}\text { Cytoplasmic dynein } \\
\text { arm assembly or } \\
\text { transport factor }\end{array}$ & $\checkmark$ & IDA + ODA defect & $\checkmark$ & $\begin{array}{l}\text { ODA component + IDA } \\
\text { component }\end{array}$ \\
\hline RSPH1, RSPH4A, RSPH9 & {$[40,59]$} & RSPH subunit & $(x)$ & $\begin{array}{l}\text { Missing CP or TTD; } \\
\text { often normal }\end{array}$ & $\checkmark$ & RSPH components \\
\hline CCDC39, CCDC40 & {$[39,60]$} & $\mathrm{NL/DRC}$ factor & $\checkmark$ & $\begin{array}{l}\text { microtubular } \\
\text { disorganisation + } \\
\text { IDA-defect }\end{array}$ & $\checkmark$ & $\begin{array}{l}\text { DRC components + IDA } \\
\text { components }\end{array}$ \\
\hline CCDC164, CCDC65 & {$[26,58]$} & NL subunit & $x$ & $\begin{array}{l}\text { NL defect only rarely } \\
\text { discernible }\end{array}$ & $\checkmark$ & NL components \\
\hline DNAHI1 & {$[36]$} & ODA subunit & $x$ & Normal & $x$ & \\
\hline HYDIN & [27] & CP subunit & $x$ & $\begin{array}{l}\text { Normal (C2b absence } \\
\text { only visible in TEM } \\
\text { tomography) }\end{array}$ & $x$ & \\
\hline CCNO, MCIDAS & {$[3,4]$} & $\begin{array}{l}\text { CCNO: cytoplasmic } \\
\text { centriole assembly } \\
\text { and docking factor; } \\
\text { MCIDAS: nuclear } \\
\text { regulator of CCNO } \\
\text { and FOXJ1 }\end{array}$ & $(x)$ & $\begin{array}{l}\text { Usually misinterpreted } \\
\text { as secondary ciliary } \\
\text { aplasia; reduced } \\
\text { numbers of MMC; } \\
\text { basal bodies and } \\
\text { rootlets are mislocalized }\end{array}$ & $(x)$ & $\begin{array}{l}\text { Usually misinterpreted as } \\
\text { secondary ciliary aplasia; } \\
\text { MCIDAS: lack of any } \\
\text { axonemal components } \\
\text { CCNO: Rootletin mislocalization, } \\
\text { CCNO deficiency }\end{array}$ \\
\hline OFD1, RPGR & {$[61,62]$} & $\begin{array}{l}\text { Functions related to } \\
\text { non-motile cilia; role } \\
\text { in motile cilia unknown }\end{array}$ & $x$ & Normal/unspecific & $x$ & \\
\hline
\end{tabular}

${ }^{a}$ Informative denotes: detectable in routine diagnostics.

$\mathrm{CP}$, central pair tubuli; DRC, dynein regulatory complex; IDA, dynein arm; IF, immunofluorescence microscopy; MMC, multiple motile cilia; NL, nexin link; ODA, outer dynein arm; RSPH, radial spoke head; TEM, transmission electron microscopy; TTD, tubular transposition defect ( $8+1$ structure).

implemented for routine diagnostics, next generation sequencing already is cost-efficient and effective in diagnosing PCD compared to traditional sequential Sanger sequencing of single genes. However, it has to be kept in mind that every year novel genetic defects are discovered and therefore genetic testing cannot be used to rule out a PCD diagnosis. In addition, expertise is necessary to distinguish mutations from rare polymorphisms.

\section{Establishing a PCD diagnosis}

Given the heterogeneity of possible findings associated with PCD, there is no uniform approach in diagnosing PCD. Currently, we consider a PCD diagnosis confirmed if the following diagnostic criteria are fulfilled: (1) clinical presentation consistent with PCD; and (2) confirmation of the diagnosis by at least two of the following methods: unequivocally abnormal HVMA finding, unequivocally abnormal TEM finding, unequivocally abnormal IF finding, abnormally low nNO concentration/production and demonstration of unequivocal biallelic disease-causing mutations by genotyping. In cases where only HVMA and nNO concentration/production are abnormal, HVMA should be repeated at least three times and show the same abnormal results each time. Individuals with typical clinical symptoms and only one abnormal diagnostic test are usually considered to have a possible PCD diagnosis with exceptions made on an individual basis (for example, identification of the same biallelic diseasecausing mutations in a subject of a sibling with a confirmed diagnosis).

Of note, this approach is provisional, as it is very likely that further research will continue to modify our understanding of different PCD phenotypes.

\section{Management}

There is a lack of evidence-based management guidelines for PCD. Randomized controlled trials have not yet been performed in this condition. Thus, therapies are deduced 
from other diseases with defective mucociliary clearance, notably CF and non-CF bronchiectasis. The PCD task force of the European Respiratory Society has issued recommendations for the management of PCD highlighting the importance of routine airway clearance techniques, the use of antibiotics to control infection, and the avoidance of harmful agents such as active and passive smoke [11].

To overcome limitations in PCD care, European and North American investigators and clinicians, as well as patient support groups, have joined forces in BESTCILIA, a European Commission funded consortium dedicated to improve PCD care and knowledge (http://www.bestcilia.eu/). Core programs of this network include: (1) A crosssectional observational trial for answering pertinent questions on clinical phenotype, severity, prognosis, and effect of treatments on outcomes; (2) An international prospective PCD registry for systematic data collection on incidence, clinical presentation, treatments, and course of the disease. This will allow to monitor trends in management and outcomes and to recruit patients for trials. (3) The introduction of standardized diagnostic testing for PCD in three European countries (Greece, Poland, Cyprus), where this is currently not available. This approach will be paradigmatic for other countries how to implement sophisticated diagnostic facilities; (4) The development of PCD-specific health-related quality of life questionnaires (QoL-PCD) as an outcome measure in clinical trials. QoL-PCD is furthermore particularly useful to track changes over time and therefore to assess changes in disease impact on daily life. Therefore, QoLPCD will be integrated into the longitudinal international PCD registry; (5) The first randomized controlled clinical trial ever performed in PCD to analyze the efficacy and safety of long-term use of azithromycin.

\section{Monitoring}

Ideally, individuals with PCD should be followed up in specialized centers every 3 months for spirometry, microbiological studies of both upper and lower airways secretions, and review of respiratory therapy techniques.

Spirometry is easy to perform, but it is an insensitive marker of lung function decline, particularly in younger patients. Therefore, assessment of disease severity using high-resolution computed tomography (HRCT) should be considered at larger intervals [63]. Magnetic resonance imaging (MRI) protocols have been developed showing good agreement with HRCT for determining extent and severity of lung disease in non-CF bronchiectasis [64]. Although inferior to HRCT with regard to speed, image contrast and spatial resolution, MRI is an excellent radiation-free tool especially for longitudinal analyses.

Possibly, determination of lung clearance index (LCI) using multiple breath washout may evolve as a tool to monitor PCD lung disease accurately and non-invasively.
It correlates well with HRCT findings in CF and is more sensitive to early changes in lung physiology. However, a recent study has failed to demonstrate a correlation between LCI and HRCT scores in PCD [65].

Monitoring of upper airways disease includes regular hearing tests that should be performed at least every 6 months in young children and every year in adults. PCD individuals are at an increased risk to develop sleep disordered breathing, particularly due to obstructive sleep apnea syndrome $[66,67]$. Even if there are currently no evidence-based data on choice and efficacy of possible treatment modalities, assessment of sleep disorders should be part of a PCD management plan.

\section{Lower airways management}

Daily airway clearance and aggressive antibiotic treatment of respiratory tract infections are treatment cornerstones of PCD lung disease. Review of individualized, ageappropriate airway clearance therapies should be part of the regular follow-up visits. No individual technique has proven superior. Although of unproven benefit, inhalation of hypertonic saline to improve cough clearance is widely used as is use of bronchodilators. Physical exercise effectuates general health improvements and therefore is encouraged. The role of inhaled rhDNase, a medication commonly used in $\mathrm{CF}$, is unclear. In non CF-bronchiectasis, rhDNase has been shown ineffective and therefore it is not regularly used in PCD [68]. Consistent with this approach, PCD patients usually do not report changes in sputum viscosity after rhDNase inhalation. Individuals with $\mathrm{PCD}$ and clear evidence of coexisting asthma can be treated with inhaled corticosteroids. Otherwise, inhaled corticosteroids should be avoided as they might bear the risk of an increased susceptibility to infections.

Antibiotic treatment of respiratory tract infections should be instituted promptly and adjusted to microbiological findings. Fever is not a reliable symptom in many PCD individuals. We recommend antibiotics if patients note an increase in sputum quantity or a change in sputum viscosity or color. The most commonly cultured pathogens are Haemophilus influenzae, Staphylococcus aureus, Moraxella catarrhalis, and Streptococcus pneumoniae [69]. Chronic Pseudomonas aeruginosa is found particularly in adults with advanced disease. It is unclear, if chronic Pseudomonas aeruginosa infection has similar detrimental effects on lung function in PCD as in CF. However, as prompt eradication of potentially harmful bacteria remains a core goal in PCD management, protocols based on those used in $\mathrm{CF}$ are recommended. Chronic Pseudomonas aeruginosa infection is often treated with nebulized antibiotics. Some centers advocate the use of long-term prophylactic antibiotics. Currently, there is no evidence for this approach. Empirical knowledge, however, supports long-term antibiotic use in children requiring 
frequent courses of antibiotics. Currently, a BESTCILIA trial is recruiting patients to test the effects of long-term Azithromycin use.

Lung surgery in PCD is usually not recommended; in selected cases of localized disease refractory to conservative management, lobectomy can be considered. Bilateral lung transplantation is a treatment option for end-stage lung failure.

\section{Upper airways management}

Impaired mucociliary clearance in the upper airways affects the nasal cavity, the paranasal sinuses, and the middle ear. Persistent nasal discharge and blockage is treated by nasal irrigation. Chronic rhinosinusitis may be treated additionally by sinonasal inhalation of hypertonic saline solution and, when infective exacerbations occur, with antibiotics. Sinus surgery for nasal polyposis bears a high risk of early recurrence and is therefore performed only in cases of severely blocked passages. Similar to the treatment of lower airways disease, topical corticosteroids are useful only in individuals with additional allergic rhinosinusitis. The role of ventilation tubes for treatment of conductive hearing loss due to chronic otitis media with effusion is controversial. Due to the impaired mucociliary clearance, PCD patients have a higher risk of developing chronic mucopurulent discharge after ventilation tube insertion $[11,70]$. Therefore, hearing aids are preferred to manage hearing loss. By contrast, a recent report suggests that hearing may be improved by ventilation tubes, and otorrhea can be controlled [71]. These controversial reports highlight the lack of evidence based medical approaches.

\section{Non-respiratory manifestations}

Congenital heart disease, when present, usually requires corrective or palliative surgery. Male or female infertility is managed with adequate reproductive techniques. However, as men with PCD are not always infertile and women only have a slightly decreased fertility (if at all), birth control measures are necessary if there is no wish to have children.

\section{Conclusions}

Many PCD individuals receive suboptimal management because there are no evidence-based treatment guidelines. Establishing the diagnosis requires several complementary tests. A multidisciplinary management approach is well recognized to benefit long-term outcomes. Regular surveillance should include lung function testing, microbiological studies, and review of airway clearing techniques. Currently, management is mainly deduced from evidence from other suppurative lung diseases.

\section{Abbreviations}

CP: Central pair tubuli; CF: Cystic fibrosis; DRC: Dynein regulatory complex; HRCT: High-resolution computed tomography; HVMA: HIGH-speed Video microscopy; IDA: Inner dynein arm; IF: Immunofluorescence; LCl: Lung clearance index; MMC: Multiple motile cilia; MRI: Magnetic resonance imaging; NL: Nexin link; nNO: Nasal nitric oxide; ODA: Outer dynein arm; PCD: Primary ciliary dyskinesia; RSPH: Radial spoke head; TEM: Transmission electron microscopy; TTD: Tubular transposition defect.

\section{Competing interests}

The authors declare that they have no competing interests.

\section{Authors' contributions}

CW drafted the first version of the manuscript, prepared further manuscript versions and undertook final editing of the manuscript. JGO provided comments and contributed to further manuscript versions. HO supervised the writing and undertook final editing of the manuscript. All authors read and approved the final manuscript.

\section{Acknowledgements}

We are grateful to the PCD individuals and their families for their participation, notably the German patient support group 'Kartagener Syndrom und Primaere Ciliaere Dyskinesie e.V'. We thank H. Olbrich for help with figure preparation and K. Vorspohl and S. Helms for excellent technical assistance. This work was supported by European Commission FP7 Grant No.: 305404 (BESTCILIA).

Received: 16 September 2014 Accepted: 10 December 2014

Published online: 22 January 2015

\section{References}

1. Afzelius BA (1976) A human syndrome caused by immotile cilia. Science 193:317-9

2. Knowles MR, Daniels LA, Davis SD, Zariwala MA, Leigh MW (2013) Primary ciliary dyskinesia: recent advances in diagnostics, genetics, and characterization of clinical disease. Am J Respir Crit Care Med 188:913-22

3. Boon M, Wallmeier J, Ma L, Loges NT, Jaspers M, Olbrich H, Dougherty GW, Raidt J, Werner C, Amirav I, Hevroni A, Abitbul R, Avital A, Soferman R, Wessels M, O'Callaghan C, Chung EMK, Rutman A, Hirst RA, Moya E, Mitchison HM, Van Daele S, De Boeck K, Jorissen M, Kintner C, Cuppens H, Omran H (2014) MCIDAS mutations result in a mucociliary clearance disorder with reduced generation of multiple motile cilia. Nat Commun 5:4418

4. Wallmeier J, Al-Mutairi DA, Chen C-T, Loges NT, Pennekamp P, Menchen T, Ma L, Shamseldin HE, Olbrich H, Dougherty GW, Werner C, Alsabah BH, Köhler G, Jaspers M, Boon M, Griese M, Schmitt-Grohé S, Zimmermann T, Koerner-Rettberg C, Horak E, Kintner C, Alkuraya FS, Omran H (2014) Mutations in CCNO result in congenital mucociliary clearance disorder with reduced generation of multiple motile cilia. Nat Genet 46:646-51

5. Storm van's Gravesande K, Omran H (2005) Primary ciliary dyskinesia: clinical presentation, diagnosis and genetics. Ann Med 37:439-49

6. Lucas JS, Burgess A, Mitchison HM, Moya E, Williamson M, Hogg C (2014) Diagnosis and management of primary ciliary dyskinesia. Arch Dis Child 99:850-6

7. Leigh MW, Pittman JE, Carson JL, Ferkol TW, Dell SD, Davis SD, Knowles MR, Zariwala MA (2009) Clinical and genetic aspects of primary ciliary dyskinesia/ Kartagener syndrome. Genet Med 11:473-87

8. Omran H (2007) Diagnostik der primären ziliären Dyskinesie. Pneumologe 4:267-75

9. Omran $\mathrm{H}$, Olbrich H (2010) Zilienkrankheiten unter besonderer Berücksichtigung der primären ziliären Dyskinesie. Medizinische Genet 22:315-21

10. Nüßlein $T$, Brinkmann $F$, Ahrens $P$, Ebsen $M$, Jung $A$, Kirchberger W, Kneißl A, Koerner-Rettberg C, Linz-Keul H, Loges NT, Theegarten D, Seithe H, Sendler J, Werner C, Omran H (2013) Diagnostik der primären ziliären Dyskinesie. Monatsschrift Kinderheilkd 161:406-16

11. Barbato A, Frischer T, Kuehni CE, Snijders D, Azevedo I, Baktai G, Bartoloni L, Eber E, Escribano A, Haarman E, Hesselmar B, Hogg C, Jorissen M, Lucas J, Nielsen KG, O'Callaghan C, Omran H, Pohunek P, Strippoli M-PF, Bush A (2009) Primary ciliary dyskinesia: a consensus statement on diagnostic and treatment approaches in children. Eur Respir J 34:1264-76

12. Kuehni CE, Frischer T, Strippoli M-PF, Maurer E, Bush A, Nielsen KG, Escribano A, Lucas JSA, Yiallouros P, Omran H, Eber E, O'Callaghan C, Snijders D, Barbato A (2010) Factors influencing age at diagnosis of primary ciliary dyskinesia in European children. Eur Respir J 36:1248-58

13. O'Callaghan C, Chetcuti P, Moya E (2010) High prevalence of primary ciliary dyskinesia in a British Asian population. Arch Dis Child 95:51-2 
14. Leigh MW, O'Callaghan C, Knowles MR (2011) The challenges of diagnosing primary ciliary dyskinesia. Proc Am Thorac Soc 8:434-7

15. Noone PG, Leigh MW, Sannuti A, Minnix SL, Carson JL, Hazucha M, Zariwala MA, Knowles MR (2004) Primary ciliary dyskinesia: diagnostic and phenotypic features. Am J Respir Crit Care Med 169:459-67

16. Kennedy MP, Noone PG, Leigh MW, Zariwala MA, Minnix SL, Knowles MR, Molina PL (2007) High-resolution CT of patients with primary ciliary dyskinesia. AJR Am J Roentgenol 188:1232-8

17. Kennedy MP, Omran H, Leigh MW, Dell S, Morgan L, Molina PL, Robinson BV, Minnix SL, Olbrich H, Severin T, Ahrens P, Lange L, Morillas HN, Noone PG, Zariwala MA, Knowles MR (2007) Congenital heart disease and other heterotaxic defects in a large cohort of patients with primary ciliary dyskinesia. Circulation 115:2814-21

18. Nakhleh N, Francis R, Giese RA, Tian X, Li Y, Zariwala MA, Yagi H, Khalifa O, Kureshi S, Chatterjee B, Sabol SL, Swisher M, Connelly PS, Daniels MP, Srinivasan A, Kuehl K, Kravitz N, Burns K, Sami I, Omran H, Barmada M, Olivier K, Chawla KK, Leigh M, Jonas R, Knowles M, Leatherbury L, Lo CW (2012) High prevalence of respiratory ciliary dysfunction in congenital heart disease patients with heterotaxy. Circulation 125:2232-42

19. Walker WT, Jackson CL, Lackie PM, Hogg C, Lucas JS (2012) Nitric oxide in primary ciliary dyskinesia. Eur Respir J 40:1024-32

20. Leigh MW, Hazucha MJ, Chawla KK, Baker BR, Shapiro AJ, Brown DE, Lavange LM, Horton BJ, Qaqish B, Carson JL, Davis SD, Dell SD, Ferkol TW, Atkinson JJ, Olivier KN, Sagel SD, Rosenfeld M, Milla C, Lee H-S, Krischer J, Zariwala MA, Knowles MR (2013) Standardizing nasal nitric oxide measurement as a test for primary ciliary dyskinesia. Ann Am Thorac Soc 10:574-81

21. Marthin JK, Nielsen KG (2011) Choice of nasal nitric oxide technique as first-line test for primary ciliary dyskinesia. Eur Respir J 37:559-65

22. Marthin JK, Nielsen KG (2013) Hand-held tidal breathing nasal nitric oxide measurement-a promising targeted case-finding tool for the diagnosis of primary ciliary dyskinesia. PLoS One 8:e57262

23. Mateos-Corral D, Coombs R, Grasemann H, Ratjen F, Dell SD (2011) Diagnostic value of nasal nitric oxide measured with non-velum closure techniques for children with primary ciliary dyskinesia. J Pediatr 159:420-4

24. Raidt J, Wallmeier J, Hjeij R, Onnebrink JG, Pennekamp P, Loges NT, Olbrich H, Häffner K, Dougherty GW, Omran H, Werner C (2014) Ciliary beat pattern and frequency in genetic variants of primary ciliary dyskinesia. Eur Respir J 44:1579-88

25. Papon J-F, Bassinet L, Cariou-Patron G, Zerah-Lancner F, Vojtek A-M, Blanchon S, Crestani B, Amselem S, Coste A, Housset B, Escudier E, Louis B (2012) Quantitative analysis of ciliary beating in primary ciliary dyskinesia: a pilot study. Orphanet J Rare Dis 7:78

26. Wirschell M, Olbrich H, Werner C, Tritschler D, Bower R, Sale WS, Loges NT, Pennekamp P, Lindberg S, Stenram U, Carlén B, Horak E, Köhler G, Nürnberg P, Nürnberg G, Porter ME, Omran H (2013) The nexin-dynein regulatory complex subunit DRC1 is essential for motile cilia function in algae and humans. Nat Genet 45:262-8

27. Olbrich H, Schmidts M, Werner C, Onoufriadis A, Loges NT, Raidt J, Banki NF, Shoemark A, Burgoyne T, Al Turki S, Hurles ME, Köhler G, Schroeder J, Nürnberg G, Nürnberg P, Chung EMK, Reinhardt R, Marthin JK, Nielsen KG, Mitchison HM, Omran H (2012) Recessive HYDIN mutations cause primary ciliary dyskinesia without randomization of left-right body asymmetry. Am J Hum Genet 91:672-84

28. Thomas B, Rutman A, O'Callaghan C (2009) Disrupted ciliated epithelium shows slower ciliary beat frequency and increased dyskinesia. Eur Respir J 34:401-4

29. Hirst RA, Jackson CL, Coles JL, Williams G, Rutman A, Goggin PM, Adam EC, Page A, Evans HJ, Lackie PM, O'Callaghan C, Lucas JS (2014) Culture of primary ciliary dyskinesia epithelial cells at air-liquid interface can alter ciliary phenotype but remains a robust and informative diagnostic aid. PLoS One 9:e89675

30. Jorissen M, Willems T, Van der Schueren B, Verbeken E (2000) Secondary ciliary dyskinesia is absent after ciliogenesis in culture. Acta Otorhinolaryngol Belg 54:333-42

31. Knowles MR, Leigh MW, Carson JL, Davis SD, Dell SD, Ferkol TW, Olivier KN, Sagel SD, Rosenfeld M, Burns KA, Minnix SL, Armstrong MC, Lori A, Hazucha MJ, Loges NT, Olbrich H, Becker-Heck A, Schmidts M, Werner C, Omran H, Zariwala MA (2012) Mutations of DNAH11 in patients with primary ciliary dyskinesia with normal ciliary ultrastructure. Thorax 67:433-41

32. Boon M, Smits A, Cuppens $H$, Jaspers M, Proesmans M, Dupont LJ, Vermeulen FL, Van Daele S, Malfroot A, Godding V, Jorissen M, De Boeck K (2014) Primary ciliary dyskinesia: critical evaluation of clinical symptoms and diagnosis in patients with normal and abnormal ultrastructure. Orphanet J Rare Dis 9:11

33. O'Callaghan C, Rutman A, Williams GM, Hirst RA (2011) Inner dynein arm defects causing primary ciliary dyskinesia: repeat testing required. Eur Respir J 38:603-7

34. Knowles MR, Ostrowski LE, Leigh MW, Sears PR, Davis SD, Wolf WE et al (2014) Mutations in RSPH1 cause primary ciliary dyskinesia with a unique clinical and ciliary phenotype. Am J Respir Crit Care Med 189:707-17

35. Horani A, Brody SL, Ferkol TW, Shoseyov D, Wasserman MG, Ta-shma A, Wilson KS, Bayly PV, Amirav I, Cohen-Cymberknoh M, Dutcher SK, Elpeleg O, Kerem E (2013) CCDC65 mutation causes primary ciliary dyskinesia with normal ultrastructure and hyperkinetic cilia. PLoS One 8:e72299

36. Schwabe GC, Hoffmann K, Loges NT, Birker D, Rossier C, de Santi MM, Schwabe GC, Hoffmann K, Loges NT, Birker D, Rossier C, de Santi MM (2008) Primary ciliary dyskinesia associated with normal axoneme ultrastructure is caused by DNAH11 mutations. Hum Mutat 29:289-98

37. Fliegauf $M$, Olbrich $H$, Horvath J, Wildhaber JH, Zariwala MA, Kennedy M, Knowles MR, Omran H (2005) Mislocalization of DNAH5 and DNAH9 in respiratory cells from patients with primary ciliary dyskinesia. Am J Respi Crit Care Med 171:1343-9

38. Omran $H$, Kobayashi D, Olbrich H, Tsukahara T, Loges NT, Hagiwara H, Zhang Q, Leblond G, OToole E, Hara C, Mizuno H, Kawano H, Fliegauf M, Yagi T, Koshida S, Miyawaki A, Zentgraf H, Seithe H, Reinhardt R, Watanabe Y, Kamiya R, Mitchell DR, Takeda H (2008) Ktu/PF13 is required for cytoplasmic pre-assembly of axonemal dyneins. Nature 456:611-6

39. Merveille A-C, Davis EE, Becker-Heck A, Legendre M, Amirav I, Bataille G, Belmont J, Beydon N, Billen F, Clément A, Clercx C, Coste A, Crosbie R, de Blic J, Deleuze S, Duquesnoy P, Escalier D, Escudier E, Fliegauf M, Horvath J, Hill K, Jorissen M, Just J, Kispert A, Lathrop M, Loges NT, Marthin JK, Momozawa Y, Montantin G, Nielsen KG et al (2011) CCDC39 is required for assembly of inner dynein arms and the dynein regulatory complex and for normal ciliary motility in humans and dogs. Nat Genet 43:72-8

40. Kott E, Legendre M, Copin B, Papon J-F, Dastot-Le Moal F, Montantin G, Duquesnoy P, Piterboth W, Amram D, Bassinet L, Beucher J, Beydon N, Deneuville E, Houdouin V, Journel H, Just J, Nathan N, Tamalet A, Collot N, Jeanson L, Le Gouez M, Vallette B, Vojtek A-M, Epaud R, Coste A, Clement A, Housset B, Louis B, Escudier E, Amselem S (2013) Loss-of-function mutations in RSPH1 cause primary ciliary dyskinesia with central-complex and radial-spoke defects. Am J Hum Genet 93:561-70

41. Onoufriadis A, Shoemark A, Schmidts M, Patel M, Jimenez G, Liu H, Thomas B, Dixon M, Hirst RA, Rutman A, Burgoyne T, Williams C, Scully J, Bolard F, Lafitte J-J, Beales PL, Hogg C, Yang P, Chung EMK, Emes RD, O'Callaghan C, Bouvagnet P, Mitchison HM (2014) Targeted NGS gene panel identifies mutations in $\mathrm{RSPH} 1$ causing primary ciliary dyskinesia and a common mechanism for ciliary central pair agenesis due to radial spoke defects. Hum Mol Genet 23:3362-74

42. Olbrich H, Häffner K, Kispert A, Völkel A, Volz A, Sasmaz G, Reinhardt R, Hennig S, Lehrach H, Konietzko N, Zariwala M, Noone PG, Knowles M, Mitchison HM, Meeks M, Chung EMK, Hildebrandt F, Sudbrak R, Omran H (2002) Mutations in DNAH5 cause primary ciliary dyskinesia and randomization of left-right asymmetry. Nat Genet 30:143-4

43. Pennarun G, Escudier E, Chapelin C, Bridoux AM, Cacheux V, Roger G, Clément A, Goossens M, Amselem S, Duriez B (1999) Loss-of-function mutations in a human gene related to Chlamydomonas reinhardtii dynein IC78 result in primary ciliary dyskinesia. Am J Hum Genet 65:1508-19

44. Loges NT, Olbrich H, Fenske L, Mussaffi H, Horvath J, Fliegauf M, Kuhl H, Baktai G, Peterffy E, Chodhari R, Chung EMK, Rutman A, O'Callaghan C, Blau H, Tiszlavicz L, Voelkel K, Witt M, Zietkiewicz E, Neesen J, Reinhardt R, Mitchison HM, Omran H (2008) DNAI2 mutations cause primary ciliary dyskinesia with defects in the outer dynein arm. Am J Hum Genet 83:547-58

45. Mazor M, Alkrinawi S, Chalifa-Caspi V, Manor E, Sheffield VC, Aviram M, Parvari R (2011) Primary ciliary dyskinesia caused by homozygous mutation in DNAL1, encoding dynein light chain 1. Am J Hum Genet 88:599-607

46. Duriez B, Duquesnoy P, Escudier E, Bridoux A-M, Escalier D, Rayet I, Marcos E, Vojtek A-M, Bercher J-F, Amselem S (2007) A common variant in combination with a nonsense mutation in a member of the thioredoxin family causes primary ciliary dyskinesia. Proc Natl Acad Sci U S A 104:3336-41

47. Onoufriadis A, Paff T, Antony D, Shoemark A, Micha D, Kuyt B, Schmidts M, Petridi S, Dankert-Roelse JE, Haarman EG, Daniels JMA, Emes RD, Wilson R, Hogg C, Scambler PJ, Chung EMK, Pals G, Mitchison HM (2013) Splice-site 
mutations in the axonemal outer dynein arm docking complex gene CCDC114 cause primary ciliary dyskinesia. Am J Hum Genet 92:88-98

48. Hjeij R, Lindstrand A, Francis R, Zariwala MA, Liu X, Li Y, Damerla R, Dougherty GW, Abouhamed M, Olbrich H, Loges NT, Pennekamp P, Davis EE, Carvalho CMB, Pehlivan D, Werner C, Raidt J, Köhler G, Häffner K, Reyes-Mugica M, Lupski JR, Leigh MW, Rosenfeld M, Morgan LC, Knowles MR, Lo CW, Katsanis N, Omran H et al (2013) ARMC4 mutations cause primary ciliary dyskinesia with randomization of left/right body asymmetry. Am J Hum Genet 93:357-67

49. Hjeij R, Onoufriadis A, Watson CM, Slagle CE, Klena NT, Dougherty GW Kurkowiak M, Loges NT, Diggle CP, Morante NFC, Gabriel GC, Lemke KL, Li Y, Pennekamp P, Menchen T, Konert F, Marthin JK, Mans DA, Letteboer SJF, Werner C, Burgoyne T, Westermann C, Rutman A, Carr IM, O'Callaghan C, Moya E, Chung EMK, Sheridan E, Nielsen KG, Roepman R et al (2014) CCDC151 mutations cause primary ciliary dyskinesia by disruption of the outer dynein arm docking complex formation. Am J Hum Genet 95:257-74

50. Loges NT, Olbrich H, Becker-Heck A, Häffner K, Heer A, Reinhard C, Schmidts M, Kispert A, Zariwala MA, Leigh MW, Knowles MR, Zentgraf $H$, Seithe $H$, Nürnberg G, Nürnberg $P$, Reinhardt R, Omran H (2009) Deletions and point mutations of LRRC50 cause primary ciliary dyskinesia due to dynein arm defects. Am J Hum Genet 85:883-9

51. Mitchison HM, Schmidts M, Loges NT, Freshour J, Dritsoula A, Hirst RA, O'Callaghan C, Blau H, Al Dabbagh M, Olbrich H, Beales PL, Yagi T, Mussaffi H, Chung EMK, Omran H, Mitchell DR (2012) Mutations in axonemal dynein assembly factor DNAAF3 cause primary ciliary dyskinesia. Nat Genet 44:381-9

52. Horani A, Druley TE, Zariwala MA, Patel AC, Levinson BT, Van Arendonk LG, Thornton KC, Giacalone JC, Albee AJ, Wilson KS, Turner EH, Nickerson DA, Shendure J, Bayly PV, Leigh MW, Knowles MR, Brody SL, Dutcher SK, Ferkol TW (2012) Whole-exome capture and sequencing identifies HEATR2 mutation as a cause of primary ciliary dyskinesia. Am J Hum Genet 91:685-93

53. Kott E, Duquesnoy P, Copin B, Legendre M, Dastot-Le Moal F, Montantin G, Jeanson L, Tamalet A, Papon J-F, Siffroi J-P, Rives N, Mitchell V, de Blic J, Coste A, Clement A, Escalier D, Touré A, Escudier E, Amselem S (2012) Loss-of-function mutations in LRRC6, a gene essential for proper axonemal assembly of inner and outer dynein arms, cause primary ciliary dyskinesia. Am J Hum Genet 91:958-64

54. Zariwala MA, Gee HY, Kurkowiak M, Al-Mutairi DA, Leigh MW, Hurd TW, Hjeij R, Dell SD, Chaki M, Dougherty GW, Adan M, Spear PC, Esteve-Rudd J, Loges NT, Rosenfeld M, Diaz KA, Olbrich H, Wolf WE, Sheridan E, Batten TFC, Halbritter J, Porath JD, Kohl S, Lovric S, Hwang D-Y, Pittman JE, Burns KA, Ferkol TW, Sagel SD, Olivier KN et al (2013) ZMYND10 is mutated in primary ciliary dyskinesia and interacts with LRRC6. Am J Hum Genet 93:336-45

55. Tarkar A, Loges NT, Slagle CE, Francis R, Dougherty GW, Tamayo JV, Shook B, Cantino M, Schwartz D, Jahnke C, Olbrich H, Werner C, Raidt J, Pennekamp P, Abouhamed M, Hjeij R, Köhler G, Griese M, Li Y, Lemke K, Klena N, Liu X, Gabriel G, Tobita K, Jaspers M, Morgan LC, Shapiro AJ, Letteboer SJF, Mans DA, Carson $\mathrm{JL}$ et al (2013) DYX1C1 is required for axonemal dynein assembly and ciliary motility. Nat Genet 45:995-1003

56. Wolf WE, Carson JL, Hazucha MJ, Yin W, Davis SD, Dell SD, Ferkol TW, Sagel SD, Olivier KN, Jahnke C, Olbrich H, Werner C, Raidt J, Wallmeier J, Pennekamp P, Dougherty GW, Hjeij R, Gee HY, Otto EA, Halbritter J, Chaki M, Diaz KA, Braun DA, Porath JD et al (2013) Mutations in SPAG1 cause primary ciliary dyskinesia associated with defective outer and inner dynein arms. Am J Hum Genet 93:711-20

57. Panizzi JR, Becker-Heck A, Castleman VH, Al-Mutairi DA, Liu Y, Loges NT, Pathak N, Austin-Tse C, Sheridan E, Schmidts M, Olbrich H, Werner C, Häffner K, Hellman N, Chodhari R, Gupta A, Kramer-Zucker A, Olale F, Burdine RD, Schier AF, O'Callaghan C, Chung EMK, Reinhardt R, Mitchison HM, King SM, Omran H, Drummond IA (2012) CCDC103 mutations cause primary ciliary dyskinesia by disrupting assembly of ciliary dynein arms. Nat Genet 44:714-9

58. Austin-Tse C, Halbritter J, Zariwala MA, Gilberti RM, Gee HY, Hellman N, Austin-Tse C, Halbritter J, Zariwala MA, Gilberti RM, Gee HY, Hellman N, Pathak N, Liu Y, Panizzi JR, Patel-King RS, Tritschler D, Bower R, O'Toole E, Porath JD, Hurd TW, Chaki M, Diaz KA, Kohl S, Lovric S, Hwang D-Y, Braun DA, Schueler M, Airik R, Otto EA et al (2013) Zebrafish ciliopathy screen plus human mutational analysis identifies C21 orf59 and CCDC65 defects as causing primary ciliary dyskinesia. Am J Hum Genet 93:672-86

59. Castleman VH, Romio L, Chodhari R, Hirst RA, de Castro SCP, Parker KA, Ybot-Gonzalez P, Emes RD, Wilson SW, Wallis C, Johnson CA, Herrera RJ, Rutman A, Dixon M, Shoemark A, Bush A, Hogg C, Gardiner RM, Reish O, Greene NDE, O'Callaghan C, Purton S, Chung EMK, Mitchison HM (2009)
Mutations in radial spoke head protein genes RSPH9 and RSPH4A cause primary ciliary dyskinesia with central-microtubular-pair abnormalities. Am J Hum Genet 84:197-209

60. Becker-Heck A, Zohn IE, Okabe N, Pollock A, Lenhart KB, Sullivan-Brown J, McSheene J, Loges NT, Olbrich H, Haeffner K, Fliegauf M, Horvath J, Reinhardt R, Nielsen KG, Marthin JK, Baktai G, Anderson KV, Geisler R, Niswander L, Omran H, Burdine RD (2011) The coiled-coil domain containing protein CCDC40 is essential for motile cilia function and left-right axis formation. Nat Genet 43:79-84

61. Budny B, Chen W, Omran H, Fliegauf M, Tzschach A, Wisniewska M, Jensen LR Raynaud M, Shoichet SA, Badura M, Lenzner S, Latos-Bielenska A, Ropers H-H (2006) A novel $X$-linked recessive mental retardation syndrome comprising macrocephaly and ciliary dysfunction is allelic to oral-facial-digital type I syndrome. Hum Genet 120:171-8

62. Moore A, Escudier E, Roger G, Tamalet A, Pelosse B, Marlin S, Clément A, Geremek M, Delaisi B, Bridoux A-M, Coste A, Witt M, Duriez B, Amselem S (2006) RPGR is mutated in patients with a complex $X$ linked phenotype combining primary ciliary dyskinesia and retinitis pigmentosa. J Med Genet 43:326-33

63. Maglione M, Bush A, Montella S, Mollica C, Manna A, Esposito A, Santamaria $F$ (2012) Progression of lung disease in primary ciliary dyskinesia: is spirometry less accurate than CT? Pediatr Pulmonol 47:498-504

64. Montella S, Maglione M, Bruzzese D, Mollica C, Pignata C, Aloj G, Manna A, Esposito A, Mirra V, Santamaria F (2012) Magnetic resonance imaging is an accurate and reliable method to evaluate non-cystic fibrosis paediatric lung disease. Respirology 17:87-91

65. Irving SJ, Ives A, Davies G, Donovan J, Edey AJ, Gill SS, Nair A, Saunders C, Wijesekera NT, Alton EWFW, Hansell D, Hogg C, Davies JC, Bush A (2013) Lung clearance index and high-resolution computed tomography scores in primary ciliary dyskinesia. Am J Respir Crit Care Med 188:545-9

66. Santamaria F, Esposito M, Montella S, Cantone E, Mollica C, De Stefano S, Mirra V, Carotenuto M (2014) Sleep disordered breathing and airway disease in primary ciliary dyskinesia. Respirology 19:570-5

67. Oktem S, Karadag B, Erdem E, Gokdemir Y, Karakoc F, Dagli E, Ersu R (2013) Sleep disordered breathing in patients with primary ciliary dyskinesia. Pediatr Pulmonol 48:897-903

68. O'Donnell AE, Barker AF, Ilowite JS, Fick RB (1998) Treatment of idiopathic bronchiectasis with aerosolized recombinant human DNase I. rhDNase Study Group. Chest 113:1329-34

69. Maglione M, Bush A, Nielsen KG, Hogg C, Montella S, Marthin JK, Di Giorgio A, Santamaria F (2014) Multicenter analysis of body mass index, lung function, and sputum microbiology in primary ciliary dyskinesia. Pediatr Pulmonol 49:1243-50

70. Majithia A, Fong J, Hariri M, Harcourt J (2005) Hearing outcomes in children with primary ciliary dyskinesia-a longitudinal study. Int J Pediatr Otorhinolaryngol 69:1061-4

71. Wolter NE, Dell SD, James AL, Campisi P (2012) Middle ear ventilation in children with primary ciliary dyskinesia. Int J Pediatr Otorhinolaryngol 76:1565-8

\section{Submit your next manuscript to BioMed Central and take full advantage of:}

- Convenient online submission

- Thorough peer review

- No space constraints or color figure charges

- Immediate publication on acceptance

- Inclusion in PubMed, CAS, Scopus and Google Scholar

- Research which is freely available for redistribution 